$1-2014$

\title{
Bringing Down an Uprising: Egypt's Stillborn Revolution
}

Sahar F. Aziz

Texas A\&M University School of Law, saziz@law.tamu.edu

Follow this and additional works at: https://scholarship.law.tamu.edu/facscholar

Part of the Law Commons

\section{Recommended Citation}

Sahar F. Aziz, Bringing Down an Uprising: Egypt's Stillborn Revolution, 30 Conn. J. Int'l L. 1 (2014). Available at: https://scholarship.law.tamu.edu/facscholar/349

This Article is brought to you for free and open access by Texas A\&M Law Scholarship. It has been accepted for inclusion in Faculty Scholarship by an authorized administrator of Texas A\&M Law Scholarship. For more information, please contact aretteen@law.tamu.edu. 


\title{
BRINGING DOWN AN UPRISING: EGYPT'S STILLBORN REVOLUTION
}

\author{
Sahar F. Aziz"
}

Abstract

Despite warnings that bleak socio-economic conditions were pushing Egyptians to the brink, few could have predicted the timing and extent of what has come to be known as the "January $25^{\text {th }}$ revolution." For the two years that followed this unprecedented revolutionary moment, many Egyptians believed their nation was headed toward a political rebirth in the direction of democratization-albeit in fits and starts. What ultimately transpired was far from a revolution, but rather an uprising. Those who risked life and limb in multiple mass protests are now in jail or dead while the military-security apparatus sits firmly at the apex of power. Rather than join other countries moving forward toward a free society, dissent in Egypt is brutally crushed harking back to Gamal Abdel-Nasser's pervasive police state.

This article seeks to answer the question on the minds of millions across the globe who witnessed Egyptians inspire the world as they rose up against a brutal authoritarian state: What happened to Egypt's revolution? In hindsight, it has become clear that the moment the Egyptian military took on the official reins of leadership through the Supreme Council of Armed Forces (SCAF) on February 11, 2011, a pall was cast on the people's revolutionary aspirations. What was supposed to be a historic political opening to transition Egypt onto a more democratic political trajectory resulted in a regression to military domination where soldiers, rather than civilians, control the levers of political, economic, and security power." As a result, Egyptians have yet to have their revolution.

* Associate professor, Texas A\&M University School of Law where she teaches Middle East Law, National Security Law, and Civil Rights Litigation. Professor Aziz also serves as the president of the Egyptian American Rule of Law Association (www.earla.org). Professor Aziz thanks Professors Nathan Brown, Asli Bali, and Andrew Morriss for their valuable feedback on earlier drafts. She also thanks Deborah Bankhead, Brian Bailey, and Travis Gasper for their excellent research assistance. The assistance of the librarian faculty at Texas A\&M School of Law was invaluable in completing this research project.

1. Jamie Dettmer, Mubarak's Acquittal Signals Complete Triumph of Military Over Arab Spring, DAILY BEAST (Nov. 29, 2014), http://www.thedailybeast.com/articles/2014/1 1/29/mubarak-sacquittal-signals-complete-triumph-of-military-over-arab-spring.html. 


\section{CONNECTICUT J OURNAL}

O F I N T ER NATIONAL LA W

\section{TABLE OF CONTENTS}

$\begin{array}{lr}\text { INTRODUCTION } & 3\end{array}$

I. WHY RISE UP?

A. ECONOMIC INEQUALITY AND THE FALL OF THE MIDDLE ClasS 9

B. A BURGEONING CIVIL SOCIETY 13

C. THE LABOR MOVEMENT ROCKS EGYPT 15

D. LOSING THE Elite COALITION IN THE 2010 PARLIAMENTARY EleCtions 17

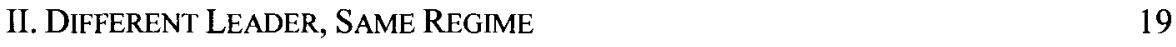

III. SAME REgIME, SAME TACTICS 23

IV. THE REAL REVOLUTION IS COMING 26 


\section{INTRODUCTION}

On January 25, 2011, the world watched in awe as millions of Egyptians poured into the streets demanding bread, freedom, and social justice; all of which they had been denied for three decades under Hosni Mubarak's deeply embedded authoritarian regime. That Egyptians had persevered economic and political indignities for so long without revolting against the regime made the events of January 25 all the more striking. Once it became evident that Egypt's despised security forces could not quash the masses, thousands of news articles, blogs, and tweets declared that Egyptians were finally revolting. ${ }^{2}$ After sixty years of authoritarianism led by retired generals, the Egyptian revolution was officially underway. But what ultimately transpired was far from a revolution.

For eighteen heart-wrenching days, Egyptians proved to the world that they were not docile subjects relegated to the status of an indefinitely oppressed people. Those who sacrificed life and limb were not simply seeking to end Mubarak's three-decade long rule, but rather to create a political regime that respected their political and civil rights. ${ }^{3}$ The message was loud and clear: Egyptians deserved a democratic system that would provide them the freedom and justice they demanded, and toward that end they demanded the removal of the regime. ${ }^{4}$ But on the eighteenth day, when Hosni Mubarak declared his resignation after thirty years as President of Egypt, what was supposed to be a revolutionary re-birth was stillborn. The moment the Egyptian military took on the official reins of leadership through the Supreme Council of Armed Forces (SCAF), a pall was cast on the people's revolutionary aspirations. ${ }^{5}$ While this conclusion was obvious to political scientists who had long studied Egypt, ${ }^{6}$ most Egyptians had not yet come to this

2. Nadia Idle \& Alex Nunns, Tahrir Square Tweet by Tweet, GUARDIAN (Apr. 14, 2011) http://www.theguardian.com/world/2011/apr/14/tahrir-square-tweet-egyptian-uprising; Kareem Fahim \& Mona El-Naggar, Violent Clashes Mark Protests Against Mubarak's Rule, N.Y. TiMES (Jan. 25, 2011), http:/www.nytimes.com/2011/01/26/world/middleeast/26egypt.html?pagewanted=all\&_r=0; Protests in Egypt and Unrest in Middle East - As it Happened, GuARDIAN (Jan. 25, 2011), http://www.theguardian.com/global/blog/2011/jan/25/middleeast-tunisia; Amir Ahmed, Thousands Protest in Egypt, CNN (Jan. 26, 2011), http:/www.cnn.com/201 1/WORLD/meast/01/25/egypt.protests/.

3. Jeannie Sowers, Egypt in Transformation, in THE JOURNEY TO TAHRIR: REVOLUTION, Protest, AND SOCIAL CHANGE IN EGYPT 1, 2 (Jeannie Sowers \& Chris Toensing eds., 2012).

4. Sean F. McMahon, Egypt's Social Forces, the State, and the Middle East Order, in EGYPT's TAHRIR REVolution 151, 157-58 (Dan Tschirgi, Walid Kazziha, \& Sean F. McMahon eds., 2013).

5. See Holger Albrecht, Authoritarian Transformation or Transition from Authoritarianism? Insights on Regime Change in Egypt, in ARAB SPRING IN EGYPT: REVOLUTION AND BEYOND 251, 26667 (Bahgat Korany \& Rabab El-Mahdi eds. 2014) (discussing the autonomy of SCAF and their unwillingness to accept a pluralist society).

6. Hend El-Behary, Hamzawy Interview: "We Are Returning to the Old Regime", EGYPT INDEP. (May 25, 2014, 11:13 PM), http://www.egyptindependent.com//news/hamzawy-interview$\% \mathrm{E} \% 80 \% 98$ we-are-returning-old-regime; Nathan J. Brown, Egypt's Failed Transition, Tracking the "Arab Spring", 24 J. DEMOCRACY 4, 45 (2013); see, e.g., Jason BrownleE, DEMOCRACY Prevention: The Politics of the U.S.-Egrptian Alliance (2012); see also IIITMedia, Professor Emad Shahin-Struggle for Democracy in Egypt, YOUTUBE (Feb. 5, 2014), https://www.youtube.com/watch?v=cLdnFVYHONs; Joel Beinin, Was there a January 25 Revolution?, JADALIYYA (Jan. 25, 2013), http://www.jadaliyya.com/pages/index/9766/was-there-a-january-25revolution. 
realization. Indeed, many still hold fast to their belief that January 25 was a revolution. ${ }^{7}$

In the heady days after January 25, it appeared that a sudden and radical political change was imminent. The security forces had been pushed into hiding, the military had declared it would not follow orders to shoot the people, Gamal Mubarak $^{8}$ and his cronies were on the run, and Hosni Mubarak's deposal was inevitable. But as soon as Field Marshall Tantawi became the top executive of the state, supported by a council of generals, the revolutionary situation was doomed to produce a non-revolutionary outcome. At the time of the January 25 uprisings, Tantawi was the head of the Egyptian military, a close confidant of President Hosni Mubarak, and a strong supporter of preserving the status quo. That Tantawi took the reins of power after the January 25 uprisings was a problematic contradiction between the protesters' demands and Tantawi's ties with the old regime. ${ }^{9}$ Facilitating this outcome was the demonstrators' failure to develop a clear agenda beyond removing Mubarak. ${ }^{10}$ Egyptians had replaced a ruler but kept the same regime under the stewardship of the same military from which its past presidents hailed. ${ }^{11}$ Indeed, what was supposed to be a historic political opening to transition Egypt onto a more democratic political trajectory resulted in a regression to an unabashed military domination where soldiers, rather than civilians, control the levers of political, economic, and security power. ${ }^{12}$

The military had long been a bulwark of Egypt's post-colonial authoritarian state. Until Anwar Sadat began to reshuffle elite coalitions to offset Nasserists' questionable loyalties, the military stood at the apex of the authoritarian state lead

7. See, e.g., David Kirkpatrick \& Merna Thomas, Egyptian Judges Drop all Charges against Mubarak, N.Y. TIMES (Nov. 30, 2014) (quoting Egyptian advocate Hossam Bahgat stating "[t]oday's verdict indicates a very deliberate decision by the regime to continue on the path of rewriting the history that led to Muabark's ouster and closing the file on the Jan. 25 revolution."); H.A. Hellyer, Egypt's Revolution on the Margins, CNN.COM (Jan. 25, 2014) http:/www.cnn.com/2014/01/25/opinion/hellyeregypt-revolution-three-years-on/; Ahmed El-Sayyed Al-Naggar, Social Justice: The Unfulfilled Dream of the Egyptian Revolution, AHRAM ONLINE (July 9, 2014), http://english.ahram.org.eg/NewsContent/4/0/105671/Opinion/Social-justice-The-unfulfilled-dream-ofthe-Egypti.aspx. But see Hosni Mubarak Verdict Due, but Egyptians' Interest Wanes, WoRLD ASSOCIATED PRESS (Nov. 28, 2014), http://www.ndtv.com/article/world/hosni-mubarak-verdict-duebut-egyptians-interest-wanes-626981 (quoting one Egyptian analyst's assessment that "[t]here's been a steady narrative to say 2011 wasn't a real revolution, the real revolution was the June 30,2013 one against Mohammed Morsi and the Muslim Brotherhood.").

8. Gamal Mubarak is the son of Hosni Mubarak who was being groomed to be the NDP's candidate for president in the next elections. This caused consternation among the military elite who wanted to preserve the tradition of having a former general preside over the nation. HOLGER ALBRECHT, RAGING AGAINST THE MACHINE: POLITICAL OPPOSITION UNDER AUTHORITARIANISM IN EGYPT 140 (2013) [hereinafter RAGING AGAINST THE MACHINE].

9. Profile: Mohammed Hussein Tantawi, BBC NEws (Aug. 12, 2012), http://www.bbc.com/news/world-middle-east-12441512; JOSHUA STACHER, ADAPTABLE AUTOCRATS: REGIME POWER IN EGYPT AND SYRIA 112 (2012) (discussing Tantawi as one of Mubarak's closest elites).

10. Albrecht, supra note 5, at 264 (noting that demonstrators failed to develop a program for political, economic, or social reforms despite having the unified aim of deposing Mubarak).

11. BROWNLEE, supra note 6, at 3; Intisar Rabb, The Lest Religious Branch? Judicial Review and the New Islamic Constitutionalism, 17 UCLA J. INT'L \& FOR. AFF. 75, 117 (2013).

12. Wael Nawara, Sisi Runs for President in Nasser's Shadow, Al-MONITOR (Mar. 26, 2014), http://www.al-monitor.com/pulse/originals/2014/03/sisi-egypt-president-nasser.html\#; 
by General Gamal Abdel Nasser. ${ }^{13}$ Mubarak continued the process as he promoted domestic security forces and the Ministry of Interior, and later Gamal Mubarak's business elite cronies, as the most influential political actors. Indeed, by 2010 , only $8 \%$ of Mubarak's ministerial appointments came from the military's ranks. ${ }^{14}$ Despite its shift away from visible forms of power under Sadat and the first half of Mubarak's rule, the military's influence was deeply entrenched within Egypt's economy. For instance, the military's industrial complex produced armaments, transport, gasoline, furniture, televisions, olive oil, and bottled water. ${ }^{15}$ It was also involved in export-import trade, construction, engineering, tourism, and farming. ${ }^{16}$ Thus, Mubarak's aggressive economic liberalization program threatened the army's economic complex, which reportedly comprised up to $40 \%$ of the economy. ${ }^{17}$ Likewise, defense expenditures decreased from 19.5\% of Gross Domestic Product in 1980 to $2.2 \%$ of GDP in 2010 . $^{18}$

Meanwhile, the Ministry of Interior received injections of funds and resources such that domestic security forces outnumbered military personnel by a factor of three-to-one. ${ }^{19}$ This reordering of the elite coalition that placed the military second to the Ministry of Interior became a major grievance of the military elite. ${ }^{20}$ Thus, January 25 provided the military with a golden opportunity to regain its throne as the most powerful state institution. ${ }^{21}$ Some scholars have gone as far as describing January 25 as a soft coup ${ }^{22}$ - an assessment corroborated by the 2014 constitution provisions that shield the military from any civilian oversight and events currently unfolding on the ground. ${ }^{23}$

While most Egyptians and many analysts believed the SCAF's promises to serve as merely a caretaker government for six months until the people could democratically select their new president, what transpired exposed this false

13. See generally Albrecht, supra note 5; see generally JASON BROWNLEE, AUTHORITARIANISM IN AN AGE OF DEMOCRATIZATION (2007) [hereinafter AUTHORITARIANISM]; see generally Amin Saikal, Authoritarianism, Revolution and Democracy: Egypt and Beyond, 65 AUSTL. J. INT'L AFF. 530 (2011).

14. STACHER, supra note 9, at 5-6 (2012).

15. Ivan Ivekovic, Egypt's Uncertain Transition, in EGYPT'S TAHRIR REVOLUTION, supra note 4, at 173,181 .

16. Id.

17. Hazem Kandil, Back on Horse? The Military Between Two Revolutions, in ARAB SPRING IN EGYPT: REVOLUTION AND BEYOND, supra note 5, at 175, 183 (discussing the decrease in the army's economic complex due to economic liberalization); STEVEN A. COOK, RULING BUT NOT GOVERNING: The Military and Political Development In EGYPT, AlgERIA, AND TURKEy 19-20 (2007).

18. Id. at 175, 183, 185 (noting that the Egyptian military still controlled a substantial portion of the manufacturing industry, producing household appliances, agricultural goods, bottled water, and military hardware. Their "off budget" kept them loyal to Mubarak's regime, albeit begrudgingly); BROWNLEE, supra note 6 , at 66.

19. STACHER, supra note 9, at 7.

20. McMahon, supra note 4 , at 159

21. Id.

22. Kandil, supra note 17, at 193 (discussing SCAF's actions as a soft coup).

23. Dalia Fahmy, Struggle for Democracy in Egypt, INT'L INST. OF ISLAMIC THOUGHT (Feb. 5, 2014), http:/www.iiit.org/NewsEvents/News/tabid/62/articleType/ArticleView/articleId/349/Default. aspx; Kandil, supra note 17, at 193; see, e.g., EGYPT 2014 ConstrTuTION, Arts. 201, 203, 204, 205, available at https://www.constituteproject.org/constitution/Egypt_2014.pdf. 
promise. $^{24}$ As discussed in detail in Section III, the SCAF spared no time in amending the constitution and issuing executive decrees that ensured their longterm political dominance. ${ }^{25}$ Such efforts culminated in General Abdel Fattah elSisi becoming Egypt's president after the military successfully orchestrated the overthrow of democratically elected Mohamed Morsi. With the benefit of hindsight three years later, it is now clear that Egypt has inched closer to a new phase of authoritarianism controlled by the military, which subsumed the domestic security forces and business elite, ruling over a population that has tasted freedom, even if only for a moment. ${ }^{26}$

For decades, Egyptian society suffered from multiple long-term problems; ones which the political system aggravated rather than alleviated. Egyptians responded with rising activism, which eventually burst forth in the January 25 , 2011 uprising. But because the political order managed to survive that uprising with only cosmetic changes, the fundamental problems remain unaddressed thereby making a prospective revolution a plausible prediction. As such, Egypt did not undergo a revolution. Indeed, even the most fundamental components of a revolution are glaringly missing from Egypt's experience: 1) a sudden, radical, or complete political, social, or economic change; ${ }^{27}$ 2) a fundamental change in political organization; and 3) the overthrow of a ruler or government. To date, no changes have occurred to the distribution of wealth and power from the privileged elite to the bulging lower classes. ${ }^{28}$

And yet, Egypt certainly experienced a revolutionary moment. ${ }^{29}$ By going out into the streets by the millions, a cross section of Egyptians comprised of a diverse multitude of small groups and individuals created a revolutionary situation in a collective act of liberation after thirty years of censorship. ${ }^{30}$ However, the failure to produce a sustainable radical departure from the pre-January 25 status quo limits the revolutionary consequence to eighteen days of uprising. The question still remains as to how this revolutionary moment will make a permanent imprint in the nation's political trajectory. Did January 25 trigger long-term political change that will eventually place sovereignty in the people, or will it be merely a temporary period of instability within a long history of authoritarianism led by Egypt's military establishment?

24. BROWNLEE, supra note 6, at 3 (noting that January 25 arose from grassroots mobilization rather than intra-regime cleavages thereby failing to eliminate authoritarianism); Kandil, supra note 17, at 193 (discussing SCAF's declaration to withdraw from politics after a six-month transition period).

25. See BROWNLEE, supra note 6, at 158 (discussing the constitutional declaration made by SCAF).

26. Id. at 155 (arguing that the U.S. supported the Egyptian military's efforts to retain power as a means of preserving U.S. interests in the region).

27. See generally Albrecht, supra note 5, at 251-70 (discussing how the January 25 uprising was more so an isolated event than a revolution in and of itself).

28. Sheila Carapico, Egypt's Civic Revolution Turns 'Democracy Promotion' on its Head, in ARAB SPRING IN EGYPT: REVOLUTION AND BEYOND, supra note 5, at 199, 221; Ivekovic, supra note 15 , at 176-77 (noting that Mubarak's economic development programs produced distorted class stratification).

29. See generally Charles TILly, From Mobilization to Revolution (1978).

30. Javed Maswood \& Usha Natarajan, Democratization and Constitutional Reform in Egypt and Indonesia: Evaluating the Role of the Military, in ARAB SPRING IN EGYPT: REVOLUTION AND BEYOND, supra note 5, at 233, 241. 
This article is part of a larger project that addresses the role of law and the judiciary in Egypt's stillborn revolution. ${ }^{31}$ As such, this article provides the political backdrop in the lead up to January 25 and the key political decisions made by the SCAF and the military-backed interim government led by President Adly Mansour, which lays the foundation for my future articles on the Egyptian judiciary and the role of law in Egypt's post-January 25 aftermath. ${ }^{32}$ In doing so, I analyze the historic events of the past three years to address the first of two pressing questions: 1) did January 25, 2011 permanently redirect Egypt's political trajectory toward a more democratic, openly contested political system; and 2) what role did the law play in producing the outcome? In forthcoming articles, I address the second question. Here, I argue that, as of the fall of 2014, Egypt shows signs of increasing political contestations at the margins while simultaneously regressing to repressive state policing practices firmly under the grip of the military. There is a growing tension between Egyptian youth's expectations of meaningful political change, ${ }^{33}$ regardless of their political or religious persuasions, and the state apparatus reverting to calls for stability at the expense of political rights. In the end, the military hijacked a revolutionary moment by transforming it into a mere uprising. ${ }^{34}$ Recognizing Egypt's missed opportunity to have the revolutionary outcome called for by its youth paves the way for an honest discussion on whether a real revolution is imminent, if not inevitable. ${ }^{35}$

\section{WHY RISE UP?}

Four factors collectively contributed toward the January 25 uprising: 1) economic inequality and the fall of the middle class: 2) a burgeoning civil society advocating for political and economic rights; 3 ) a resilient labor movement actively employing street protests; and 4) the 2010 parliamentary elections tainted by unprecedented levels of fraud that fissured Mubarak's elite coalition. The accumulation of festering economic and political grievances culminated in Egypt's January 25 uprising. Growing mass discontent arising from extreme wealth disparities, rising unemployment, unchecked systemic corruption, a deteriorating infrastructure, and a political system left little room for citizens to determine their

31. See Sahar F. Aziz, Theater or Transitional Justice: Reforming Egypt's Judiciary, in Transitional JUSTICE IN THE MidDLE EAST (forthcoming Fall 2015) (on file with author); Sahar F. Aziz, The Perils of Judicial Independence: Egypt's Judiciary and Counter-Revolution (work in progress) [hereinafter The Perils of Judicial Independence].

32. See Aziz, supra note 31; The Perils of Judicial Independence, supra note 31.

33. See Earl (Tim) Sullivan, Youth Power and the Revolution, in EGYPT's TAHRIR REVOLUTION, supra note 4, at 67,69-72 (discussing the well-educated demands of revolutionary youth); April 6 Youth Movement: Their Demands, PBS, http://www.pbs.org/wgbh/pages/frontline/revolution-in-cairo/insideapril6-movement/ (last visited Nov. 14, 2014); Statement of the April 6 Movement Regarding the Demands of the Youth and the Refusal to Negotiate with Any Side, JADALIYYA (Feb. 6, 2011), $\mathrm{http} / /$ www.jadaliyya.com/pages/index/579/statement-of-the-april-6-movement-regarding-the-demandsof-the-youth-and-the-refusal-to-negotiate-with-any-side.

34. Ivekovic, supra note 15, at 183-84 (noting the SCAF's perception of the popular revolt movement as its main enemy).

35. See generally Brown, supra note 6 (discussing the status of Egypt's political atmosphere and whether the a true revolution occurred or the recent events were a mere uprising). 
political fate. ${ }^{36}$ Fully cognizant of the complexity of the challenges facing their society, most Egyptians knew better than to expect quick fixes. What they expected, however, was a democratic political system that guaranteed them basic human and civil rights and empowered them to create a more accountable, less corrupt government that served the people. ${ }^{37}$ Specifically, Egyptians wanted the freedom to speak, assemble, and participate in public affairs to apply equally to all citizens. $^{38}$

Political rights were not merely abstract goals. Rather, Egyptians sought them in furtherance of attaining wealth redistribution, equal opportunities for employment especially among educated youth, and wage increases after decades of stagnation. ${ }^{39}$ Toward those ends, a burgeoning civil society and emboldened labor movement became increasingly vocal about their discontent. ${ }^{40}$ Due to prohibitions against public protests, youth used social media and the Internet to mobilize around common grievances. ${ }^{41}$ In outright defiance of laws prohibiting labor strikes, laborers across the country refused to work until they received desperately needed pay increases that employers had reneged on. ${ }^{42}$ These developments at the margins of political life were insufficient to produce the historic moment on January 25 . It was Mubarak's grooming of his son Gamal to become the next president and Gamal's capitalist cronies pushed the military-security elites further down the power hierarchy ${ }^{43}$ that made Egypt ripe for a traumatic political crisis. While the political elite sought to merely change leadership, citizens sought to change the entire regime.

The consequent historic opportunity for revolutionary change, however, was lost soon after the uprisings ended when the military coopted the revolutionary moment with the surreptitious support of the Muslim Brotherhood. ${ }^{44}$

36. See generally Nadia Ramsis Farah, The Political Economy of Egypt's Revolution in EGYPT'S TAHRIR REVOLUTION, supra note 4, at 47; Ivekovic, supra note 15, at 217.

37. As Egyptians observed Eastern European countries free themselves from the clutches of Communist authoritarianism, they were left wondering why they could not attain such freedom. See Thomas Obel Hansen, The Vertical and Horizontal Expansion of Transitional Justice: Explanations and Implications for a Contested Field, in TRANSITIONAL JUSTICE THEORIES 105, 110-112 (Susanne Buckley-Zistel, Teresa Koloma Beck, Christian Braun, \& Frederike Mieth eds., 2014); see RaGING AGAINST THE MACHINE, supra note 8, at xix-xxi.

38. See Maswood \& Natarajan, supra note 30 , at 225 (discussing the rights associated with a democratic government); see Hansen, supra note 37, at $111-12$.

39. See Tarek Masoud, Counting Islam: Religion, Class and Elections in Egypt 127 (2014) (discussing citizens call for wealth redistribution); see Sullivan, supra note 33, at 69-72 (discussing the well-educated demands of revolutionary youth).

40. See Vickie Langohr, Too Much Civil Society, Too Little Politics: Egypt and Liberalizing Arab Regimes, 36 COMP. POL. 181, 181-82 (2004).

41. See, e.g, Joel Beinin, The Working Class and the Popular Movement in Egypt, in THE JOURNEY TO TAHRIR: REVOLUTION, PROTEST, AND SOCIAL CHANGE IN EGYPT, supra note 3, at 92, 12729 (discussing the use of Facebook to rally labor strikes in Mahalla for bonuses reneged on by the government).

42. Id.

43. Reem Abou-El-Fadl, Beyond Conventional Transitional Justice: Egypt's 2011 Revolution and the Absence of Political Will, 6 INT'L J. TRANSITIONAL JUST. 318, 322-23 (2012); Albrecht, supra note 5, at 253-54; ROger OWEN, THE RISE AND FALl OF ARAB PRESIDENTS For LiFE 49-51(2012).

44. See, e.g., Ivekovic, supra note 15, at 182-83; Sherine El Ghatit, Revolution without Islamists?, in EGYPT'S TAHRIR REVOLUTION, supra note 4, at 109, 117-20. 


\section{A. Economic Inequality and the Fall of the Middle Class}

The rising poverty decimating the middle class was arguably the most significant impetus for the 2011 populist uprising. ${ }^{45}$ Wages of most Egyptian workers were insufficient to pay for food, clothing, shelter, and education. As the government ratcheted up economic liberalization and privatization, subsidy reduction resulted in a $30 \%$ increase in gasoline prices in the summer of $2006 .{ }^{46}$ Skyrocketing food prices on the international market increased the cost of food while salaries lagged behind. ${ }^{47}$ From 2005 to 2008 , the cost of staples such as milk, cheese, eggs, and beans increased by 100 to $150 \% .{ }^{48}$ Vegetables and cooking-gas cylinders also cost more, disproportionately hurting the lower middle class and poor. ${ }^{49}$ In mid-2010, the price of rice went up by $50 \%$, meat prices rose by $40 \%$ and poultry by $25 \%$. The increases could not be absorbed by state subsidies, leaving more Egyptians facing food insecurity. ${ }^{50}$ Meanwhile, the gap between income and the cost of supporting a family increased among both blue and white collar employees. In 2010, most working class families with two wage earners lived below the poverty line, ${ }^{51}$ when the average monthly wage of a typical textile worker was between $\$ 45$ and $\$ 107$ per month. ${ }^{52}$

At the time of the uprising, most Egyptians' real wages had contracted so much that approximately $20 \%$ of Egyptians fell below the poverty line while another $25 \%$ hovered just above it. ${ }^{53}$ All the while, a small group of crony capitalist elites turned politicians used the National Democratic Party to change laws to transfer state funds to their personal businesses. ${ }^{54}$ Starting in the early 1990s when Egypt could no longer evade international pressures to liberalize its

45. Mohsen Al Attar, Counter-Revolution by Ideology? Law and Development's Vision(s) for Post-Revolutionary Egypt, 33 THIRD WORLD Q. 1611, 1619 (2012).

46. BROWNLEE, supra note 6 , at 127 ("[G]asoline prices rose 30 percent in the summer of 2006.").

47. Albrecht, supra note 5, at 254; Beinin, supra note 41, at 104-05 (discussing how low wages for Egyptian workers were inadequate to pay for food); BROWNLEE, supra note 6, at 127 (discussing "rising food prices and stagnant wages.").

48. BROWNLEE, supra note 6, at 127 ("[T] eggs, and beans, shot up by 100 to 150 percent.").

49. Id.

50. Beinin, supra note 41 , at 105 (summarizing a World Bank report finding that "nearly $44 \%$ of Egyptians are 'extremely poor' (unable to meet minimum food needs), 'poor' (unable to meet basic food needs), or 'near-poor' (able to meet basic food needs, but not much more).").

51. Joel Beinin, Egyptian Workers Demand a Living Wage, ForEIGN POL'Y (May 12, 2010), http://mideastafrica.foreignpolicy.com/posts/2010/05/12/egyptian_workers_demand_a_living_wage [hereinafter Egyptian Workers Demand].

52. Id.

53. Ahmed Farouk Ghoneim, Egypt and Subsidies: A Country Living Beyond Its Means, MID. EAST INST. (May 5, 2014), http://www.mei.edu/content/egypt-and-subsidies-country-living-beyond-itsmeans; Al Attar, supra note 45, at 1617; Albrecht, supra note 5, at 253-54 ("20 percent of the population were considered to fall below the poverty line and another 20 percent struggled on the verge of that line.").

54. See, e.g., M. Cherif Bassiouni, Corruption Cases Against Officials of the Mubarak Regime, EGYPTIAN AM. RULE OF LAW ASS'N (Mar. 23, 2012), available at http://www.earla.org/userfiles/file/Bassiouni\%20Corruption\%20Cases\%20Against\%20Mubarak_EARL A $\% 20$ Letterhead\%20\%28march\%202012\%29.pdf (providing a briefing of a number of corruption cases against leaders of the NDP party). 
market, a small group of state-subsidized, super-rich businessmen subverted purported economic liberalization and became further enriched by the gradual selloff of state companies. ${ }^{55}$ They lived in exclusive, luxury gated communities in the outskirts of Cairo and vacationed in expensive beach homes on the Mediterranean and Red Sea. ${ }^{56}$ As the rich parasitically siphoned off the state's treasury, most Egyptians could not find enough to eat or obtain adequate housing. ${ }^{57}$

Massive labor migrations starting in the $1970 \mathrm{~s}^{58}$ turned Cairo into a teeming metropolitan city with over 17 million inhabitants. ${ }^{59}$ Poor Egyptians scrabbled together the little resources they had to build shanty homes without the necessary permits or meeting zoning and safety standards, causing the expansion of shantytowns to cope with Cairene overcrowding. ${ }^{60}$ To light their homes and access water, they tapped into the state's electrical grid and pipes without government approval. ${ }^{61}$ And yet, over 10.6 million more apartments than households lay vacant in 2006 because most Egyptians could not afford to purchase the millions of vacant apartments. ${ }^{62}$ The rise in poverty was attributable largely to rising unemployment even though school enrollment reached its highest levels wherein $94 \%$ of children were enrolled in primary school, $88 \%$ were enrolled at the secondary level, and $35 \%$ were enrolled in high school. ${ }^{63}$ Although literacy rose significantly from $40 \%$ in 1990 to $64 \%$ in 2010 , the quality of public education had plummeted. ${ }^{64}$ Minimal funds were invested into the public education system resulting in overcrowded schools, overworked and underpaid teachers, and a low quality public education system. ${ }^{65}$ These youth, who were formally educated but unprepared to compete in the job market, expected to find jobs and live a better quality of life than their

55. See Farah, supra note 36, 54 ("Twenty-nine public enterprise companies were sold. ...").

56. Sowers, supra note 3, at 11 ; see also Albrecht, supra note 5, at 259.

57. Eric Denis, Demographic Surprises Foreshadow Change in Neoliberal Egypt, in THE JOURNEY TO TAHRIR: REVOLUTION, PROTEST, AND SOCIAL CHANGE IN EGYPT, supra note 3, at 235, 239; Amina Kheiri, Egypt's Slums: A Ticking Time Bomb, AL-MONITOR (Nov. 7, 2013), http://www.almonitor.com/pulse/politics/2013/1 1/egypt-slums-ticking-time-bomb.html.

58. Regina Kipper, Cairo: A Broader View, in CAIRo's INFORMAL AREAS BETWEEN URBAN Challenges AND HidDEn Potentials 13, 18 (Regina Kipper \& Marion Fischer eds., 2009).

59. Jessica Winegar, Taking Out the Trash: Youth Clean Up Egypt after Mubarak, in THE JOURNEY to TAHRIR: REVolution, PROTEST, AND Social CHANGE IN EGYPT, supra note 3, at 64, 65 (discussing a population surge in Cairo to approximately 17 million).

60. See, e.g., Azizur Patel, Is Islamism on Trial in Post-Arab Spring Egypt?, 1 RIMA Occasional Papers No. 13, 2 (2013); see generally Richard Harris \& Malak Wahba, The Urban Geography of LowIncome Housing: Cairo (1947-96) Exemplifies a Model, 26 INT'L J. URB. \& REG'L RES. 58 (2002).

61. Winegar, supra note 59, at 64-65 (noting that the government did not provide clean water, affordable housing, or trash collection to the increasing rural poor migrating to urban areas); Patel, supra note 60 ("[M]illions of Egyptians lived in wretched shantytowns without basic human necessities.").

62. Denis, supra note 57 , at 239

63. Dina Shehata, Youth Movements and the 25 January Revolution, in ARAB SPRING IN EGYPT: REVOLUTION AND BEYOND, supra note 5, at 105, 107.

64. Al Attar, supra note 45, at 1618; UNESCO, ADULT AND YouTH LITERACY, 1990-2015: ANALYSIS OF DATA FOR 41 SELECTED COUNTRIES (2012), available at http://www.uis.unesco.org/Education/Documents/UIS-literacy-statistics-1990-2015-en.pdf (detailing the literacy statistics for the Egyptian youth in 1990 and 2010).

65. Louisa Loveluck, Education in Egypt: Key Challenges, CHATHAM HouSE 4 (Mar. 2012) available at http://www.chathamhouse.org/sites/files/chathamhouse/public/Research/Middle\%20East/ 0312egyptedu_background.pdf. 
parents. $^{66}$ Their unfulfilled aspirations drove them to join the throngs of protesters in 2011.

By 2010 , more than 850,000 people entered the labor force every year. ${ }^{67}$ Approximately $75 \%$ of new entrants had to wait an average of five years to find their first job, with college educated youth experiencing the highest rates of unemployment. ${ }^{68}$ Indeed, $95 \%$ of the jobless youth were college educated in 2006, up from $87 \%$ in $1998 .{ }^{69}$ Although the Egyptian economy experienced greater than a fourfold growth, the wealth was not trickling down to middle class and poor Egyptians. ${ }^{70}$ Indeed, privatization of state owned enterprises contributed to high youth unemployment rates, as the government historically had been a major employer of new college graduates. ${ }^{71}$ From 1985 to 2004 , employment in the public sector was halved from 1.08 million to less than $500,000{ }^{72}$ The formal private sector was unable to absorb the same number of new labor entrants. ${ }^{73}$ Instead, over $75 \%$ of new labor force entrants worked in the informal sector in 2004 compared to $30 \%$ in $1985 .{ }^{74}$ By 2006 , the informal sector constituted $61 \%$ of actual employment and produced one third to one half of officially measured GDP. ${ }^{75}$

Nevertheless, proponents of economic liberalization touted Egypt's official decrease in unemployment from $11.7 \%$ in 1998 to $8.3 \%$ in $2006 .^{76}$ Economists, however, pointed out that this reduction came at the cost of quality employment. Law No. 53 of 1984 was amended in 2003 to allow employers to hire workers on short-term contracts without medical or social insurance benefits. ${ }^{77}$ The 2003 amendments to the labor law stripped employees of labor rights by failing to protect the length of contract, the salary level, the hours at work, over-time compensation, vacation, or lunch breaks. ${ }^{78}$ Moreover, employers were not required to provide health and injury insurance. ${ }^{79}$ To evade the law's minimal employee protections, employers forced new hires to sign a form that allowed the employer to

66. Shehata, supra note 63, at 105, 107 (noting that Egypt and the Middle East suffered from the highest levels of youth unemployment in the world).

67. Id. at 107 .

68. Id.

69. Id.

70. Ivekovic, supra note 15 , at 176-77.

71. Loveluck, supra note 65 , at 3.

72. Karen Pfeifer, Economic Reform and Privatization in Egypt, in THE JOURNEY TO TAHRIR: Revolution, Protest, and Social Change in EgYPT, supra note 3, at 203, 207-08.

73. Id.

74. Pierre-Richard Agénor, Mustapha K. Nabli, Tarik Youset, \& Henning Tarp Jensen, Labor Market Reforms, Growth, and Unemployment in Labor-Exporting Countries in the Middle East and North Africa 56 (World Bank Publications, Working Paper No. 3328, 2004) available at http://wwwwds.worldbank.org/external/default/WDSContentServer/IW3P/IB/2004/11/08/000090341_2004110814 1652/Rendered/PDF/wps3328.pdf.

75. Id.

76. Denis, supra note 57 , at 238.

77. Ann M. Lesch, Concentrated Power Breeds Corruption, Repression, and Resistance, in ARAB SPRING IN EGYPT: REVOLUTION AND BEYOND, supra note 5, at 17, 26.

78. Id.

79. Id. 
fire them without warning, cause, or severance pay. ${ }^{80}$ All the while the monthly minimum wage had not been raised since 1984 , which was the equivalent of $\$ 25^{81}$ Were it not for remittances sent from the millions of Egyptians working abroad, millions more Egyptians would have been living in poverty. ${ }^{82}$

The high youth unemployment and job insecurity forced youth to delay getting married and setting up their own households. ${ }^{83}$ As their hopes for financial and social independence were dashed, educated youth unable to immigrate abroad had a personal stake in opposing the authoritarian state. With more than half of Egypt's population under the age of thirty, and a third between the ages of 15 and 24, the pressure for economic and political reform had reached explosive levels. ${ }^{84}$ Youthled activist organizations such as the April 6 Movement, Kefaya, and Youth for Change were action-oriented rather than based on well-defined ideologies. ${ }^{85}$ They sought what their peers in other countries had attained - human rights, economic rights, democracy, and social justice. ${ }^{86}$ While they adopted a more consensual approach to unite Egyptians, as compared to the more established political parties, the movements they created were less conciliatory with the regime. Youth rejected the government's delay tactics and rejected the Mubarak regime's top-down incremental reform approach. Instead, they demanded comprehensive political change originating at the community level. ${ }^{87}$

Further adding to Egyptians' daily tribulations was the police's constant harassment of people on the street, particularly the poor. They demanded bribes from shopkeepers and minivan drivers, free food from street vendors and restaurants, and seized anyone unable to pay the bribes. ${ }^{88}$ Police targets were beaten and tortured to coerce false confessions or pressured to become informers. ${ }^{89}$ By the end of 2010, the police became the most loathed public institution across the country. The public violence and burning of police stations during the uprising was a testament to just how far police brutality had pushed Egyptians. ${ }^{90}$

As their frustrations grew, more youth joined organized associational life by creating new advocacy organizations that were more aggressive than their predecessors in openly challenging the abusive practices of the Mubarak regime, as well as using the international media to pressure reforms within Egypt. ${ }^{91}$

80. Id.; Denis, supra note 57 , at 238 (noting that most household today cope with job insecurity, low-wage work, and inflation).

81. Lesch, supra note 77 , at 26.

82. Pfeifer, supra note 72, at 207-08 (noting that remittances rose from $\$ 3$ billion in 2000-2003 to $\$ 5$ billion in 2004-2005).

83. Ted Swedenberg, Imagine Youths, in THE JOURNEY TO TAHRIR: REVOLUTION, PrOTEST, AND SOCIAL CHANGE IN EGYPT, supra note 3, at 285, 285-86.

84. Shehata, supra note 63 , at 107.

85. Id. at 118 .

86. Id. at 117 .

87. See id. at 118 (discussing how the new generation "has focused more on consensus building and direct action rather than on ideological squabbles.").

88. Lesch, supra note 77 , at 19.

89. Id.; STACHER, supra note 9, at 146.

90. Samer Soliman, The Political Economy of Mubarak's Fall, in ARAB SPRING IN EgYPT: REVOLUTION AND BEYOND, supra note 5, at 43, 56.

91. David J. Kramer, Egypt's NGO Raids are a Full-Frontal Assault on Civil Society, WASH. POST (Mar. 11, 2012), http://www.washingtonpost.com/opinions/egypts-ngo-raids-are-a-full-frontal- 


\section{B. A Burgeoning Civil Society}

Compared to other Arab countries, Egyptian civil society has a long track record as a stakeholder in the Egyptian political and economic landscape. Most Egyptian civil society organizations are professional associations, charities, universities, and community betterment groups. ${ }^{92}$ Among the network of social service providers, many are affiliated with the heavily scrutinized Muslim Brotherhood ("MB"). ${ }^{93}$ Since 1954, when Nasser accused the Muslim Brotherhood of attempting to assassinate him, the group has been criminalized and its political activities pushed underground. ${ }^{94}$ Under Sadat, who strategically employed Islamist rhetoric to build political legitimacy among a pious population, the MB was held at arm's length out of distrust for its political ambitions. ${ }^{93}$ Nonetheless, the extensive social services the MB provided through free health clinics, orphanages, food distribution, and educational activities for youth earned them broad support among rural Egyptians and the urban poor. ${ }^{96}$ Indeed, it was these support networks that gave the MB a competitive advantage in the 2012 elections that produced an MBdominated parliament and ultimately voted in Mohamed Morsi as the first democratically elected president. ${ }^{97}$ Despite the MB's growing popularity arising from its social services, the state had little choice but to allow their social service organizations to operate to offset its own failure to feed, clothe, shelter, and educate Egypt's burgeoning poor. ${ }^{98}$ Meanwhile, only a handful of organizations historically focused on human rights, political rights, or economic rights - all of which the regime deemed off limits to civil society.

Starting in the 1990s, non-governmental advocacy groups were established, focusing on human rights, women's rights, and democratization. Although their reach was limited to the Egyptian intelligentsia and international NGOs, advocacy groups such as the Hisham Mubarak Legal Center, the Egyptian Organization for Human Rights, the Arab Network for Human Rights Initiative, the Cairo Institute for Human Rights Studies, and Al Nadeem set the foundation for the influx of civil society groups founded in the 2000s. ${ }^{99}$ Organizations such as the Egyptian Initiative for Personal Rights, the Association for Freedom of Thought and Expression, the New Woman's Foundation, and others took on more politically

assault-on-civil-society/2012/03/11/gIQAPljx5R_story.html (discussing the raids on both Egyptian and International NGOs in Egypt); Aye Nader, Human Rights Group Collaborate to Fight against Egyptian NGO Law, DAILY NEwS EGYPT (Aug. 31, 2014), http:/www.dailynewsegypt.com/2014/08/31/humanrights-group-collaborate-fight-egyptian-ngo-law/ (discussing Egyptian NGOs and International NGOs rallying together against the implementation of the new NGO law).

92. Carapico, supra note 28 , at 204.

93. MASOUD, supra note 39, at 219.

94. Id.; AUTHORITARIANISM, supra note 13, at 55.

95. Rabb, supra note 11 , at 90 (detailing the Islamist rhetoric used by Nasser); RAGING AGAINST THE MACHINE, supra note 8, at 98 (discussing the political distrust of the Muslim Brotherhood).

96. Masoud, supra note 39, at 157; Dan Tschiri, Walid Kazziha, \& Sean F. McMahon, Egypt in the Balance, in EGYPT'S TAHRIR REVOLUTION, supra note 4, at 257, 260-61.

97. MASOUD, supra note 39 , at $157,213$.

98. Id. at 4 ("[S]ocial services and other goods that the state should, but does not, provide.").

99. See, e.g., HISHAM MUBARAK LEGAL CENTER, http://hmlc-egy.org (last visited June 3, 2013); THE EGYPTIAN ORGANIZATION FOR HUMAN RIGHTS, http://en.eohr.org (last visited June 3, 2013); ARABIC NETWORK FOR HUMAN RIGHTS INITIATIVE, http://www.anhri.net/en (last visited June 3, 2013); AL NADEEM, http://www.alnadeem.com (last visited June 3, 2013). 
sensitive issues such as rural and urban poverty, deteriorating environmental conditions, harassment of women, restrictions on the press, policy coercion, and fraudulent elections. ${ }^{100}$ By 2007 , over 24,000 civil society organizations operated in Egypt, dozens of which advocated openly for political and economic rights. ${ }^{101}$

Despite the regime's efforts to employ draconian regulatory laws to rein in civil society, ${ }^{102}$ the new youth-based groups proved difficult to control. They communicated and mobilized using social media that security forces could not suppress as easily as street protests or in-person meetings. ${ }^{103}$ Youth activists engaged in boycotts, protest art, and cyber-activism to elude security forces' attempts to silence them. ${ }^{104}$ For example, the April 6 Movement mobilized over 70,000 tech savvy youth using Facebook. They demanded free speech rights, economic welfare, and an end to massive corruption. ${ }^{105}$ Their efforts culminated in a wildly successful general strike on April 6, 2008 that counted more than 1.7 million demonstrators in support of striking textile workers. ${ }^{106}$ The Internet also allowed the more established advocacy NGOs to broaden their reach by disseminating their findings widely rather than in a limited number of physical reports. $^{107}$

As a result, the decade leading up to the January 25 uprising saw myriad forms of mobilization. From the protest movements against the wars on Iraq in 2003 and Gaza in 2008, to the labor protests spreading throughout the country, Egyptians were increasingly turning to the streets to express their grievances. ${ }^{108}$ But had it not been for the rise of the labor movement, it likely would have taken much longer than eighteen days to depose Mubarak.

100. Bahgat Korany, Egypt and Beyond: the Arab Spring, the New Pan-Arabism, and the Challenges of Transition, in ARAB SPRING IN EGYPT: REVOLUTION AND BEYOND, supra note 5, at 271, 286; Asef Bayat, The "Arab Street", in THE JOURNEY TO TAHRIR: REvolution, Protest, AND SOCIAL CHANGE IN EGYPT, supra note 3, at 73, 78-79; see 15 Independent Right Groups Condemn the Expansion in the Jurisdiction of Military Courts, CAIRO INST. FOR HUMAN RIGHTS STUDIES (Oct. 30, 2014), http://www.cihrs.org/?p=9639\&lang=en (discussing the NGOs and advocacy groups active in Egypt).

101. U.N. Econ. \& Soc. Comm. for Western Asia, Soc. Dev. Div., Soc. Policy Section, Policy Brief: Looking the Other Way: Street Children in Egypt (Mar. 2009), at 14, available at http://www.escwa.un.org/divisions/div_editor/Download.asp?table_name=divisions_other\&field_name $=$ ID\&FileID $=1260$.

102. Langohr, supra note 40, at 193 (detailing Egyptian Law 32 which put severe restrictions on NGOs); Egypt: Government Moves to Restrict Rights and Democracy Groups, HUMAN RIGHTS WATCH (Sep. 26, 2011), http:/www.hrw.org/news/2011/09/26/egypt-government-moves-restrict-rights-anddemocracy-groups.

103. See Korany, supra note 100 , at 286 (discussing how new media escapes both hierarchy and governmental control).

104. Bayat, supra note 100 , at 81 .

105. Id. at 83; Abou-El-Fadl, supra note 43, at 322-23.

106. Bayat, supra note 100, at 83; STACHER, supra note 9, at 7 ("more than 1.7 million Egyptians participated in more than nineteen hundred strikes"); Sowers, supra note 3, at 7 (discussing 1.7 million Egyptian laborers protesting).

107. Lesch, supra note 77, at 32.

108. Id. 


\section{The Labor Movement Rocks Egypt}

Since the 1950s, all forms of labor strikes in Egypt have been illegal without approval by the state-sponsored Egyptian Trade Union Federation (ETUF) and its national or local affiliates. ${ }^{109}$ As a result, labor was severely restricted in its ability to challenge abusive employer practices. Nonetheless, in the mid-1980s and early 1990s, Egypt experienced strike waves primarily confined to state-owned industries. ${ }^{110}$ As state-owned enterprises were sold to private investors, managers cut labor costs to make the companies more attractive to investors. ${ }^{111}$ Mass layoffs forced early retirements, and pension reductions were among some of the measures taken against workers already struggling to make ends meet. ${ }^{12}$ As more public companies became privatized, labor actions increased, reaching an average of 100 per year from 1998 to $2003 .{ }^{113}$ The sale of state entities became more rapid when Mubarak appointed Ahmed Nazif as Prime Minister in 2004. Nazif led the charge to accelerate liberalization through privatization, floating exchange rates, and reducing income taxes and customs, all the while freezing government wages and salaries. ${ }^{114}$ Privatization occurred through various means, resulting in the sale of 379 state-owned enterprises of which 313 were total sales and 63 were sold as joint ventures. Compared to $\$ 1.92$ billion from privatization sales from 1997-2003, the government earned $\$ 9.3$ billion from privatization from 2004 to $2010 .^{115}$ Instead of improving the welfare of Egyptians, the privatization efforts enriched a small circle of cronies associated with Gamal Mubarak and Ahmed Nazif. At the same time, the new private owners fired or forced into retirement scores of employees, producing an official overall unemployment rate of $9 \%$ in 2010 and $23 \%$ unemployment for Egyptians under 25 years of age. ${ }^{116}$ The labor cuts doubled the number of strikes from 2004 to 2006 to approximately 200 per year. ${ }^{117}$

Growing discontent culminated in 2006 when 20,000 textile workers in Mahalla struck for three days after the Nazif government breached its promise to give a two-month bonus. ${ }^{118}$ For workers whose regular wages had not been raised since 1984 despite skyrocketing inflation, the additional funds were essential to

109. Beinin, supra note 41 , at 92 .

110. Id.

111. BrownleE, supra note 6, at 127; Dina Bishara, The Power of Workers in Egypt's 2011 Uprising, in ARAB SPRING IN EGYPT: REVOLUTION AND BEYOND, supra note 6, at 83, 85.

112. BROWNLEE, supra note 6 , at 127.

113. Id.

114. Farah, supra note 36 , at 54 .

115. Id.

116. Id.; Egypt, Arab Rep., WORLD BANK (2015), http://data.worldbank.org/country/egypt-arabrepublic ( $9 \%$ unemployment in 2010); Unemployment Rate Rises to 13 Percent, EGYPT INDEP. (Feb. 2, 2013), http://www.egyptindependent.com/news/unemployment-rate-rises-13-percent ( $9.8 \%$ unemployment in 2010).

117. BROWNLEE, supra note 6, at 127; Sowers, supra note 3, at 7; Egypt 2012, AFrICAN ECONOMIC OUTLOOK http://www.africaneconomicoutlook.org/fileadmin/uploads/aeo/PDF/Egypt\%20Full\%20PDF\%20Countr y\%20Note_01.pdf (last visited Dec. 24, 2014).

118. BROWNLEE, supra note 6, at 127 ("20,000 textile workers in Mahalla struck for three days"); Lesch, supra note 77, at 34-35 (discussing the Mahalla protest). 
their survival. ${ }^{119}$ At the same time, the Mubarak regime boasted that Egypt's Gross Domestic Product had reached $7 \%$ for three consecutive years from 2006 to $2008 .^{120}$ Egyptian labor bore the brunt of an investment climate welcoming to crony investors who wanted minimal restrictions on how they could treat their workers as a means of cutting costs. ${ }^{121}$

As private owners further exploited workers with short-term contracts, inadequate pay, and minimal benefits, the number of strikes increased. ${ }^{122}$ Indeed, after 2006, Egypt experienced "the longest and strongest wave of worker protest since the end of World War II."123 Labor conditions were so bad that historically complacent government employees joined confrontational blue-collar workers in protests. ${ }^{124}$ Over 2,100 strikes and other labor actions took place from 2006 to 2009. In total, over three million workers launched between 3,500-4,000 collective actions in the twelve years preceding January $25 .{ }^{125}$ Despite draconian laws and government-controlled unions, Egyptian labor became more effective at pressuring the government to grant it concessions, albeit through reactive gestures rather than sustainable solutions. ${ }^{126}$ This only emboldened labor to further mobilize. ${ }^{127}$

Although the labor movement boasted a much larger constituency than political groups engaged in protests, they focused exclusively on improving labor conditions and wrestling the labor unions from government control. ${ }^{128}$ Labor leaders did not push for a national political agenda. Nor did they connect their labor grievances with broader political corruption and the regime's abuse of power. ${ }^{129}$ Nevertheless, over a decade of labor strikes, sit-ins, and demonstrations by millions of workers set the stage for the January 25 uprising that toppled a thirty-year dictator. Indeed, it was when labor joined the uprising in earnest on February 8, 2011, that Mubarak's political death knell rang. As over one million workers went on strike throughout the country, the economy came to a near standstill. ${ }^{130}$ At this point, Hosni Mubarak and his son's cronies had become a political liability to the ruling oligarchy, causing the military to abandon Mubarak

119. BROWNLEE, supra note 6, at 127. In addition to more pay, workers called for independent union leadership rather than the government-controlled General Union of Textile Workers. Despite some compromises on bonuses, the regime held fast to its centralization of labor unions as a means of controlling an increasingly contentious labor section. $I d$.

120. World Development Indicators: Egypt, Arab Rep., WORLD BANK, http://databank.worldbank.org/data/views/reports/tableview.aspx?isshared=true (last visited June 3, 2014).

121. Albrecht, supra note 5, at 253-54 (discussing the effects of the economic climate and crony capitalists on labor workers in Egypt).

122. Beinin, supra note 41 , at 92 . Forty percent of protesting workers after 2008 were employed in the private sector. Id.

123. Bishara, supra note 111 , at 85 .

124. Id. at 86 .

125. Beinin, supra note 41 , at 92 .

126. Id.

127. Bishara, supra note 111 , at 86 .

128. BROWNLEE, supra note 6 , at 124 .

129. Id. at 128 .

130. Bishara, supra note 111, at 96-97; Sowers, supra note 3, at 7. 
to pave the way for another military man to rule, Mohamed Hussein Tantawi followed by current president Abdel Fattah el-Sisi. ${ }^{131}$

Although a dictator had been removed, the dictatorship was not gone. Instead, what occurred was a shuffle in the elite coalitions that pushed aside Gamal Mubarak and his National Democratic Party ("NDP") allies while reinstating the military and its allies as the new rulers. The revolutionary youth's outsider status, and consequent lack of political experience, doomed them to the margins of politics. The MB's experience in Egyptian politics made it privy the brutality of the state. Muslim Brotherhood leadership, thus, understood that they could not be elected to power without making a deal with the military shortly after Mubarak's deposal. ${ }^{132}$ While publicly supporting the revolutionary youth's demands and antiregime stance, the $\mathrm{MB}$ colluded with the $\mathrm{SCAF}$ to reassure the military that an $\mathrm{MB}$ government would defer to the military and not interfere with its economic interests. ${ }^{133}$ These two seasoned political actors, and longtime adversaries, had little in common except that they both sought to exploit the youth to further their separate intentions to rule Egypt. In the end, the military proved itself to be a duplicitous partner that never intended to pass on the reins of power to the established opposition, but rather use it as a ruse to appease public outrage after Egypt's historic uprising.

\section{Losing the Elite Coalition in the 2010 Parliamentary Elections}

Authoritarians do not rule alone and Mubarak was no exception. ${ }^{134} \mathrm{He}$ relied on a coalition of elites who had vested interests that his regime remained in power. In this patron-client relationship, elites obtained access to resources in exchange for their political loyalty and willingness to expel other elites unwilling to play by the rules. ${ }^{135}$ The NDP served as the primary vehicle through which elites hoarded state resources. Thus, nomination to run for parliament became a means of rewarding past loyalty as well as securing future allegiance. ${ }^{136}$

In a centralized political system controlled by Mubarak and his executive branch, the NDP was a weak and depoliticized institution. Few members were loyal to the party, but rather sought to employ it as a means of membership in the elite coalition. Doing so entailed plum political appointments, access to government contracts, and a place in an NDP-dominated parliament. ${ }^{137}$ Elites competed in elections for the privilege of acting as intermediaries in patron-client

131. Seth Galinsky, Protests Grow against Dictatorship in Egypt, MiLITANT (Feb. 21, 2011), http://www.themilitant.com/2011/7507/750701.html.

132. See, e.g., Ivekovic, supra note 15, at 182-83 (noting MB's political cooperation with the SCAF); El Ghatit, supra note 44 at 117-18.

133. El Ghatit, supra note 44 at 117-18.

134. STACHER, supra note 9 , at 35.

135. Id. at 79-80.

136. For in depth discussions on the role of the National Democratic Party in Egyptian politics under Mubarak, see, e.g., ASEF BAYAT, MAKING ISLAM DEMOCRATIC: SOCIALIST MOVEMENTS AND THE POST-ISLAMIST TURN (2007); Rabab El-Mahdi, Enough! Egypt's Quest for Democracy, 42 CoMP. POL. STUD. 1011 (Aug. 2009).

137. Samer S. Shehata, Political $\mathrm{Da} \mathrm{W}^{\prime} \mathrm{Wa}$, in ISLAMIST Politics IN THE MIDDLE EAST: Movements AND CHANGE 120, 125 (Samer Shehata ed., 2012). 
relations. ${ }^{138}$ With that came access to state resources and significant financial benefits. The electoral outcome, thus, reflected the winners and losers among various elites competing for power within the NDP. The People's Assembly held no real power in serving as a check on executive authority, making parliamentary elections merely an executive tool for perpetuating the patron-client relationship that kept Mubarak in power. ${ }^{139}$

After thirty years of authoritarian politics, most Egyptian voters had accepted this reality and, as a result, did not bother to vote. ${ }^{140}$ When they did, ruling party candidates deployed armed thugs to intimidate opposition supporters. ${ }^{141}$ Likewise, security forces fraudulently engineered electoral outcomes by stuffing ballots in favor of the NDP, creating inaccurate voter registration lists, and destroying ballots cast for opposition candidates. ${ }^{142}$ In districts with a strong opposition following, central security forces used tear gas, rubber bullets, and live ammunition to prevent citizens from voting. ${ }^{143}$ Because they posed the only real competition to NDP candidates in parliamentary elections, Muslim Brotherhood candidates were regularly targeted during elections by being routinely detained and imprisoned during pre-election raids. ${ }^{144}$ Meanwhile, NDP candidates intervened in elections with impunity through ballot stuffing and other forms of election fraud. ${ }^{145}$ Opposition parties and civic associations were permitted to participate in politics so long as they did not win enough seats to alter the status quo. This allowed the regime to claim to international critics that Egypt was a democracy while ensuring the regime's dominance. ${ }^{146}$

The 2010 elections arguably shattered the Mubarak regime's stronghold over the political elite - a key component of his political survival. By most accounts, the 2010 parliamentary elections were the most fraudulent in Egypt's history. ${ }^{147}$

138. Id.

139. Mona El-Ghobashy, The Praxis of the Egyptian Revolution, in THE JOURNEY TO TAHRIR: Revolution, PROTEST, AND Social CHANGE IN EGYPT, supra note 3, at 21, 21 (noting that the parliament was viewed as merely a "décor" and an empty shell devoid of real power).

140. Mona El-Ghobashy, The Dynamics of Elections Under Mubarak, in THE JOURNEY TO TAHRIR: REVOLUTION, PROTEST, AND SOCIAL CHANGE IN EGYPT, supra note 3, at 132, 134 [hereinafter Dynamics of Elections]; SHEHATA, supra note 63, at 122 (describing the 1995 legislative election as particularly violent with over 50 deaths and hundreds of injuries and the 2000 elections as somewhat less violent with 10 casualties and hundreds of injuries); Voter Turnout Data for Egypt, INT'L INST. FOR DEMOCRACY \& ELECTORAL ASSISTANCE: http://www.idea.int/vt/countryview.cfm?CountryCode=EG (last visited Aug. 8, 2014) (citing that the voter turnout percentage for parliamentary elections was $28.13 \%$ in $2005,27.47 \%$ in $2010,62.04 \%$ in 2012).

141. Issandr El Amrani, Controlled Reform in Egypt: Neither Reformist nor Controlled, in THE JOURNEY to TAHRIR: REVOLUTION, PROTEST, AND SOCIAL CHANGE IN EGYPT, supra note 3, at 149, 153; AUTHORITARIANISM, supra note 13, at 135-36 ("[T] he Ministry of Interior increasingly employed uniformed and plainclothes thugs to suppress voters.").

142. Dynamics of Elections, supra note 140, at 145 (discussing stuffing ballot boxes for NDP); AUTHORITARIANISM, supra note 13, at 127.

143. SHEHATA, supra note 63, at 121 ; BROWNLEE, supra note 6 , at 84 (discussing how in the 2005 elections, police cordoned off and blocked polling stations where voters turned out in support for opposition candidates).

144. SHEHATA, supra note 63, at 122.

145. El Amrani, supra note 141 , at 153.

146. El-Ghobashy, supra note 139, at 21.

147. Dynamics of Elections, supra note 140, at 133. 
Established political opposition groups, including the Muslim Brotherhood and the Wafd Party, were nearly shut out from parliament as $97 \%$ of parliamentary seats went to the NDP. ${ }^{148}$ Street battles occurred in dozens of districts across the country as police attacked voters and opposition leaders at unprecedented levels. ${ }^{149}$ These events occurred during a period when the regime was conducting systemic crackdowns on the media, university students, and cultural expression. Private businessmen pressured by the regime fired outspoken editors, opinion writers, and talk show hosts who criticized the government. ${ }^{150}$

The NDP's handling of the 2010 elections proved to be fatal for Mubarak's political future. Not only were they rigged at an unprecedented level, but the election results furthered the exclusion of the old political elites. ${ }^{151}$ Since 2002, Gamal Mubarak had taken control of the NDP and installed his crony-capitalists in powerful positions in the party, the Cabinet, and Parliament. Consequently, Hosni Mubarak's longtime inner circle of military and domestic security elites was increasingly marginalized. $^{152}$ For instance, Safwat al-Sharif, Yusif Wali, and Kamal al-Shazli were among the longest-serving and most prominent elites whose closeness to Mubarak granted them extensive patronage networks. ${ }^{153}$ But as Gamal created his own elite coalition and placed them in key cabinet positions, his father's cronies gradually lost influence. ${ }^{154}$ The 2010 elections continued this reshuffling of the elite coalition, causing members of the elite to defect and run as independent candidates. The NDP may have won the battle to control the parliament, but January 25 proved that it lost the war. And the Egyptian military was all too eager to accommodate the people's demands to ban a political party condemned as irreparably corrupt and a facilitator of Mubarak's dictatorship. ${ }^{155}$

\section{DIFFERENT LEADER, SAME REGIME}

Although the military has been a powerful institution since Egypt's 1952 military coup, ${ }^{156}$ Egypt's war against terrorism waged in the 1990s transformed the Ministry of Interior into the most powerful institution. ${ }^{157}$ By 2010, Egypt's active military personnel were outnumbered by domestic security services by a factor of three-to-one with approximately 1.5 million men serving in the Ministry of

148. Lesch, supra note 77, at 18; El-Ghobashy, supra note 139, at 26

149. SHEHATA, supra note 63, at 122 (noting at least 13 people were killed and hundreds of others were injured during the 2010 elections); Lesch, supra note 77 , at 18.

150. Lesch, supra note 77 , at 24.

151. El-Ghobashy, supra note 139 , at 26.

152. See STACHER, supra note 9, at 94 (discussing the elite coalition change as a strategy to reorganize and redistribute power within the elite arena).

153. Id. at $98-100,102$. Sfwat Al-Sharif served as information minister from 1983 to 2004 and president of the Shura Council and NDP secretary-general from 2002-2011; Yusif Wali served as agriculture minister from 1982-2004 and NDP secretary-general from 1984-2002; and Kamal al-Shazli served as parliamentary affairs minister from 1984 to 2005 . Id. at 98 .

154. Id. at 105.

155. Maswood \& Natarajan, supra note 30, at 238.

156. STACHER, supra note 9, at 4 (indeed under Mubarak generals accounted for most presidential appointments as provincial governors).

157. Id. at 6 . 
Interior. ${ }^{158}$ Counting the army of plainclothes thugs, agent provocateurs, and informers that constitute the Interior Ministry's undercover community, security forces may have reached as high as 3 million. ${ }^{159}$ The lower ranks of the police hailed from the expanded paramilitary Central Security Forces (CSF) of whom $60 \%$ were uneducated and from poor families. ${ }^{160} \mathrm{CSF}$ police were effectively indentured policemen receiving two meals a day and four dollars a month, compounding their resentment of the affluent security and business elites that translated into violence against the public. ${ }^{161}$

The police not only deal with crime, but also have decisive authority in every sphere of public life and institutions. ${ }^{162}$ They issue passports, drivers' licenses, and birth and death certificates. ${ }^{163}$ State security forces vet and approve appointments of university presidents, deans, judges, and professors. ${ }^{164}$ They determine the eligibility of graduate teaching assistants, choice of textbooks, and which faculty may travel abroad based on opaque national security criteria. ${ }^{165}$ State security can even bar students from running in university elections. Anyone affiliated with the Muslim Brotherhood, the most powerful political opposition, was often vetoed. By 2010, Egypt looked more like a security state than the military state that had predominated in the previous four decades. ${ }^{166}$

As the executive's demand for internal security grew, so too did the Ministry of Interior's budget. Some experts estimate that Egypt's total security budget was at $\$ 1.5$ billion in 2006 , which was more than the nation's health care budget. ${ }^{167}$ With that came a reduction in state expenditures on the army. ${ }^{168}$ To economically survive, the regime granted the army more leeway to build its parasitic exploitation of state assets and the authority to develop large economic industries, construction companies, and service projects. ${ }^{169}$ The military became the largest landowner with extensive business and commercial interests, placing it beyond civilian oversight. ${ }^{170}$ The profits funded its security budget as well as private hotels, sporting clubs, grocery stores and other civilian businesses available exclusively or at a discount to military personnel. ${ }^{171}$ This left the military with much to lose

158. OWEN, supra note 43 , at 47

159. Id. (nonuniformed employees played an increasing role in breaking up peaceful antigovernment demonstrations, sit-ins, and rallies); STACHER, supra note 9, at 7.

160. BROWNLEE, supra note 6, at 53.

161. Id.

162. AlaA Al Aswany, On the State of Egypt: What Made the Revolution InEvitable 24 (2011).

163. El-Ghobashy, supra note 139, at 24.

164. Lesch, supra note 77 , at 25.

165. Id.

166. STACHER, supra note 9, at 7 .

167. OWEN, supra note 43 , at 47.

168. STACHER, supra note 9, at 6.

169. Soliman, supra note 90 , at 56 (discussing the armies increased financial autonomy and ability to develop construction companies).

170. OWEN, supra note 43 , at 45.

171. STACHER, supra note 9 , at 5 . 
should a post-January 25 government act on public demands for systemic economic and political reforms. ${ }^{172}$

Moreover, starting in 2004, when Gamal Mubarak's ally Ahmed Nazif was appointed prime minister, the economy came under the control of a small group of businessmen within Gamal's inner circle. ${ }^{173}$ As 40 million Egyptians lived at or below the poverty line, this cabal ran the economy based on their personal interests. ${ }^{174}$ They purchased government land far below market value, unjustly enriched themselves through privatization of public companies, and monopolized the steel and energy sectors. ${ }^{1 / 5}$ The military resented Gamal's rise. Not only did he have no former military service, but his so-called economic liberalization projects were effectively resource grabs infringing on the military's economic turf. ${ }^{176}$ The military was protective of its shadow economy, reportedly comprising as much as $40 \%$ of Egypt's economic output, because much of the profits enriched senior military leaders and went towards the military's budget. ${ }^{177}$ Hence Gamal's rise risked shifting state resources from military elites to his civilian crony capitalist friends. For the military, this warranted accommodating public demands to remove their commander in chief on February 11, 2011.

In the euphoria that struck Egypt upon Mubarak's forced departure, few noticed the military's ingenious move to occupy the apex of a deeply entrenched authoritarian political system. Having no other institution to turn to, Egyptians welcomed the military's willingness to serve as the caretaker government until democratic processes could be implemented. Little did they know the ulterior motives at play within a military leadership keen on regaining what it saw as its rightful place as the nation's political and economic kingpins.

Facilitating the transition in leadership without a change in regime was Egypt's centralized political system, composed of depoliticized institutions formed around loyalty to the president as opposed to common ideological or institutional interests. Mubarak had masterfully centralized loyalty to the chief executive's office instead of the institution in which a particular elite member was based. By relying on the executive for fringe benefits and access to a patronage network, the elite coalition has a vested interest in serving as agents for maintaining the political system. ${ }^{178} \mathrm{In}$ the end, the authoritarian system is highly adaptive such that even if the chief executive is removed, the system remains intact. ${ }^{199}$

172. Kristen Stilt, The End of "One Hand": The Egyptian Constitutional Declaration and the Rift Between the "People" and the Supreme Council of the Armed Forces, 16 Y.B. ISLAMIC \& MID. E. L. 43, 44 (2012).

173. AL ASWANY, supra note 162, at vii; STACHER, supra note 9 , at 6.

174. AL ASWANY, supra note 162, at vii.

175. BROWNLEE, supra note 6 , at 156 (describing allegations of Gamal and Alaa Mubarak accepting villas in Sharm El Sheikh in exchange for facilitating underpriced land purchases to their friends); STACHER, supra note 9, at 6 (noting steel magnet Ahmed Ezz's near-monopoly over the Egyptian steel industry).

176. Maswood \& Natarajan, supra note 30, at 238.

177. Sahar F. Aziz, Egypt's Protracted Revolution, 19 No. 3 HUM. RTS. BRIEF 1, 3 (2012); Ivekovic, supra note 15 , at 181 .

178. STACHER, supra note 9, at 78, 79, 118.

179. Id. at 81-82; Brown, supra note 6 , at 53 . 
As a result, a reshuffling of the ruling elite, while retaining the executiveheavy political system, preserved Egypt's authoritarian form of governance. ${ }^{180}$ When the regime was threatened, the SCAF slyly replaced Hosni Mubarak within the centralized lines of authority. ${ }^{181}$ Instead of changing the entire regime as demanded by the millions protesting in the January 25 uprising, the SCAF merely altered the ruling coalition by eliminating Gamal's crony economic team and redisciplined the internal security forces as secondary to the military. ${ }^{182}$

The SCAF employed legal tactics to authorize and expand its rule. Exploiting the public's euphoric state of disbelief that Mubarak was finally gone, the SCAF carefully manipulated a public referendum on whether parliamentary elections should precede the drafting of a new constitution. Despite the referendum's narrow mandate, the SCAF successfully foisted onto the country a constitutional declaration that preserved its grip on power. ${ }^{183}$ The SCAF unilaterally appointed an unrepresentative committee of eight experts to draft 9 articles that would serve as Egypt's interim constitution. ${ }^{184}$ As part of the MB's deal with the SCAF, Tariq Al Bishri, a retired judge with Islamist leanings, headed a committee that included a Muslim Brotherhood leader, Sobhi Saleh, but excluded other opposition parties, women, and leaders of the January 25 uprising. ${ }^{185}$ Rather than respond to the revolutionaries' demands for an inclusive process, the SCAF treated the public as subjects to manipulate or ignore. ${ }^{186}$

The constitutional referendum was approved by $77 \%$ of voters on March 19 , 2011. ${ }^{187}$ Despite a narrow public mandate to amend nine articles of the 1971 Constitution, eleven days later the SCAF unilaterally abrogated the 1971 Constitution altogether and issued a sixty-three article interim constitutional declaration that superseded the approved constitutional amendments. ${ }^{188}$ The SCAF's scheme glaringly emulated Mubarak-era authoritarian tactics wherein the nation's executive imposed its will on the people under the guise of law. ${ }^{189}$ Article 189 , for example, was amended to effectively allow the presidential election process to be delayed indefinitely without affecting the constitutional process. The new Article 61 continued the SCAF's governance role until both parliamentary and presidential elections are completed, making any delay in elections a basis for prolonged SCAF rule despite its promises to serve as a short-term caretaker

180. STACHER, supra note 9 , at $78,159-60$.

181. Brown, supra note 6, at 45.

182. STACHER, supra note 9 , at $81-82,158$.

183. Brown, supra note 6 , at 47.

184. Nathalie Bernard-Maugiron, Egypt's Path to Transition: Democratic Challenges Behind the Constitution Reform Process, 3 MidDlE E. L. \& GovernanCE 43, 55 (2011).

185. Stilt, supra note 172 , at 44.

186. BROWNLEE, supra note 6, at 158.

187. The Arab World In Transition: Constitutional Timelines for Tunisia, Egypt, and Libya, LIBERTAS CONST. CONSUlTiNG, http://www.libertascc.com/\#!timelines/cl3mv (last visited Nov. 17, 2014) ("March 19, 2011: In a referendum, 77\% of Egyptian voters (18.5 million people) declared in favor of the proposed constitutional amendments.").

188. See id. ("SCAF issues a 62-article interim Constitution/Constitutional Declaration"); Stilt, supra note 172 , at $46,48-49$.

189. Stilt, supra note 172 , at 48 . 
government. $^{190}$ Moreover, the absence of most of the 1971 Constitution's provisions resulted in the SCAF retaining significant powers and discretion to issue decrees to resolve issues not addressed in the constitutional declaration. ${ }^{191}$ In the end, the SCAF served as both the legislative and executive branch until elections were held. ${ }^{192}$

Hence, in the fall of 2011 when the SCAF announced its plans to postpone the presidential elections by two years, its motives to extend its rule became more apparent. ${ }^{193}$ To ensure the next constitution protected its interests, the SCAF issued a set of "supra-constitutional principles" authorizing it to appoint 80 of the 100 members of the forthcoming constituent assembly tasked with drafting Egypt's new constitution. $^{194}$ At this point, the SCAF's motive to simply replace Mubarak without changing the regime became glaringly clear to those who spearheaded the revolution.

Within the first few weeks after January 25, the potential of Egypt's historic revolutionary moment was doomed to be little more than a historic uprising. The military swiftly planted its stake at the top of a centralized authoritarian regime supported by de-politicized institutions and a fractured elite vested in the status quo. By the time the Tahrir revolutionaries and other opposition groups discovered this, it was too late. It was business as usual but for a different authoritarian at the helm. ${ }^{195}$

\section{SAME REgIME, SAME TACTICS}

Although the youth revolutionaries realized the SCAF's subversion tactics by the summer of 2011, many Egyptians did not take notice until mid-2011. ${ }^{196}$ Egyptians could not fathom having sacrificed so much only to be left with a new variation of the same authoritarian system. Thus, the youth returned to the streets in the summer and fall of 2011 calling on the SCAF to go. ${ }^{197}$ But as the people's calls for systemic reforms became louder, the SCAF responded as would other militaries in an authoritarian state - through state violence and criminalization of dissent. Labor, youth revolutionaries, and others who criticized the SCAF's Mubarak-era tactics were whisked away by the thousands into military courts, subject to police raids or criminally prosecuted under draconian SCAF decrees. ${ }^{198}$

190. Id. at 50; Brutality Unpunished and Unchecked, AMNESTY INT'L 1 (2012), available at https://www.amnesty.nl/sites/default/files/public/2012_-_09_-_brutality_unpunished_english.pdf ("As Egypt's caretaker government, SCAF broke its promises.").

191. Stilt, supra note 172, at 51-52.

192. Bernard-Maugiron, supra note 184, at 45.

193. David Amold, SCAF's Pre-Election Moves in Egypt Could Upend Revolution, MIDDLE E. VolCES (Nov. 16, 2011), http://middleeastvoices.voanews.com/2011/11/scafs-pre-election-moves-inegypt-could-upend-revolution.

194. Id.

195. Bernard-Maugiron, supra note 184 , at 48.

196. Albrecht, supra note 5, at 265; Sowers, supra note 3, at 2.

197. See Ivekovic, supra note 15, at 183-84 (discussing youth revolts in July 2011).

198. BROWNLEE, supra note 6, at 158-59 ("The junta answered their critics with censorship, detentions and police raids. The SCAF expanded military trails against civilians and referred more than 10,000 civilians to military courts. Thousands of other dissidents lingered in legal purgatory or faced military tribunals."). 
Female protesters were subjected to virginity tests to deter others from joining the ongoing protests. ${ }^{199}$ Taking from Mubarak's playbook, the SCAF justified its actions on the need to preserve national unity and prevent public discord. ${ }^{200}$

Unaccustomed to public criticism, the military drew "a red line" around itself and its activities. ${ }^{201}$ Anyone caught overstepping this arbitrary line was quickly whisked away to a military court. Indeed, in its first six months in power, the SCAF tried more than 10,000 civilians in military trials - more than the total tried under Mubarak's thirty year rule. ${ }^{202}$ Meanwhile, Mubarak's family and cronies were charged in conventional courts where evidentiary and procedural standards were higher. ${ }^{203}$

Meanwhile, labor strikes continued throughout Egypt. With a corrupt national labor union disinterested in representing laborers' rights, workers had no other venue but street protests. ${ }^{204}$ Thousands of workers including airport and public transport workers, ambulance drivers, and even police participated in street protests. Despite Mubarak's removal, laborers had still not received their top demands - an increase in the unlivable low minimum wage, removing corrupt union leaders, improving working conditions, and providing permanent contracts to temporary workers. ${ }^{205}$ Rather than negotiate, the SCAF responded by unilaterally issuing a decree on March 23, 2011 criminalizing worker strikes that disrupted production. ${ }^{206}$ But after years of labor strikes under a repressive police state, laborers were battle hardened and willing to take on a police force now frightened of an angry public. Despite the SCAF's attempts to preserve the structure of the authoritarian system, Egyptians were no longer afraid to protest loudly and regularly.

When SCAF announced in November 2011 that the presidential elections would be postponed, thereby extending the SCAF's control of the executive branch, Egypt nearly exploded. ${ }^{207}$ Youth, liberal, and Islamist revolutionaries headed back to the square to salvage their uprising as the media exposed the SCAF's duplicitous scheme. Finding itself the latest target of mass public anger, the SCAF had no choice but to move forward with elections in June 2012. By then, the SCAF's post-January 25 political capital was spent. In early spring 2011 , eighty-eight percent of Egyptians believed the military played a positive role and

199. Egypt: A Year After 'Virginity Tests', Women Victims of Army Violence Still Seek Justice, AMNESTY INT'L (Mar. 13, 2012), http:/www.amnesty.org/en/news/egypt-year-after-virginity-testswomen-victims-army-violence-still-seek-justice-2012-03-09; Vanessa Ortiz, Hidden in Egypt's Closet: Virginity Testing as a Tactic of Repression, WAGING NONVIOLENCE (Dec. 5, 2011), $\mathrm{http}$ //wagingnonviolence.org/feature/hidden-in-egypts-closet-virginity-testing-as-a-tactic-of-repression/.

200. Albrecht, supra note 5, at 267.

201. Ursula Lindsey, Revolution and Counterrevolution in Egyptian Media, in THE JOURNEY TO TAHRIR: REVOLUTION, PROTEST, AND SOCIAL CHANGE IN EGYPT, supra note 3, at 53, 62.

202. Abou-El-Fadl, supra note 43, at 328 (2012).

203. BROWNLEE, supra note 6, at 158.

204. Beinin, supra note 41 , at 106 ("Since their [labor] unions do not represent them adequately, and they are not a party to the negotiations with the generals over Egypt's political future, street protest is the only vehicle workers have for assuring their demands.").

205. Bishara, supra note 111, at 98; see Farah, supra note 36, at 60 (discussing Egypt's Independent Trade Unionists demands for a livable wage and the removal of corrupt managers in 2011).

206. Sowers, supra note 3 , at 7 .

207. BROWNLE, supra note 6, at 159. 
ninety percent approved of General Tantawi. ${ }^{208}$ By October of 2011, two-fifths of Egyptians believed the SCAF was subverting the gains of the revolution. ${ }^{209}$

Little did Egyptians realize that the revolutionary moment had already been hijacked into a mere uprising. While Egyptians certainly had more political space to debate, engage in political contestations, and vote in relatively free and fair elections than they had experienced in their lifetime, the military firmly established itself as the political overseer with veto power. Any future president who did not protect the military's economic interests, completely defer to it on national security decisions, and accept a subordinated role was doomed to fail. And thus was the fate of Egypt's first democratically elected president, Mohamed Morsi.

On its face, the election of a Muslim Brotherhood candidate to the presidency was revolutionary in Egypt. After decades of state repression, the Muslim Brotherhood won a majority in the 2012 parliament and won the presidency in June 2012. After decades in hiding, they established their first political party as well as new television stations and newspapers. But long before Morsi occupied the presidential palace, key institutions had decided that he would fail should he attempt to change the regime's structure. While Morsi and the MB made serious political missteps, the military, judiciary, domestic security forces, and the media all coalesced to prevent meaningful changes in governance, what they ominously called the "Brotherhoodization"' of Egyptian society. That Morsi showed signs that he was more interested in exchanging Mubarak-era elites with Muslim Brotherhood loyalists without major changes to the power structure only made him more vulnerable to the so-called "deep state's" agenda. ${ }^{210}$

To be sure, the institutions that comprise the deep state were intent on fighting any changes to the regime's power structure regardless of whether it came from the Muslim Brotherhood, the revolutionary youth, labor, or any other non-elite political outsider. ${ }^{211}$ The centralized, authoritarian political system was so deeply entrenched that eighteen days of nonviolent protests could not possibly have uprooted it. Indeed, the events taking place in the fall 2014 at the writing of this article show that Egyptians were naïve in believing that they could change a deeply entrenched regime buttressed by powerful state institutions without a protracted conflict that uprooted the regime as opposed to merely decapitating it. That said, Egypt's new leaders should be cognizant that the same economic, social, and political factors that contributed towards the January 25 uprising still fester, making the likelihood

208. Id.

209. Id.

210. Tschiri, Kazziha, \& McMahon, supra note 96, at 261-62; Samuel Tadros, Islamists Respond to the 'End of Islamism'", HUDSON INST. (Mar. 11, 2014), http://www.hudson.org/research/10170islamists-respond-to-the-end-of-islamism- ("[A] failure that in practice meant they appointed loyal but unqualified members to government positions."); Sarah Childress, The Deep State: How Egypt's Shadow State Won Out, FRONTLINE (Sept. 17, 2013), http://www.pbs.org/wgbh/pages/frontline/foreignaffairs-defense/egypt-in-crisis/the-deep-state-how-egypts-shadow-state-won-out/ (defining the deep state as "Egypt's deep state is dominated by the military, but is supported by four other branches: the intelligence services, which work closely with the military to maintain political control; the police, which act as the public face of the deep state; the judiciary, which is packed with Mubarak-era judges; and the state media, which maintains staunch support of the military, airing patriotic music and video.").

211. Brown, supra note 6 , at 45,53 . 
of a future revolution quite real. And this is precisely why President Sisi is attempting to criminalize civil society, crush the labor, and impose prohibitively high costs to Egyptians' liberty and lives for opposing his regime. ${ }^{212}$

\section{THE REAL REVOLUTION IS COMING}

Only after many years have passed will we know precisely what caused Egypt's revolutionary moment to be hijacked into a mere uprising. Some will argue the Muslim Brotherhood and former president Mohamed Morsi shoulder the blame for pushing Egyptians back into the arms of the military. Others will blame the dysfunction and incompetence of secular, liberal groups to effectively campaign and win in electoral politics. Still, others will revert to Orientalist stereotypes that Egyptians are not ready for democracy and thus incapable of living in a pluralistic society without a strong military man as their leader. And while surely many complex factors contributed to Egypt's failure to transition out of an authoritarian system, one thing became clear shortly after Egyptians rose up on January 25: Egypt's military had never ceased to rule Egypt. ${ }^{213}$ Nor would it allow any civilian government, particularly one run by the Muslim Brotherhood, to usurp its power. ${ }^{214}$ Indeed, the January 25 uprising provided the military with a golden opportunity to regain its position at the top of the power hierarchy for the foreseeable future.

Nevertheless, that Egypt successfully held relatively free and fair parliamentary and presidential elections is no small feat. It signifies Egyptians' desire to transform their political system into one based on the will of the people rather than the barrel of a tank. But the authoritarian state was so deeply entrenched and its patronage network spread so far across every major state institution that eighteen days of nonviolent protests was not enough to upend it. To be sure, the system was shaken and the top political echelon was punished, albeit minimally and only temporarily. ${ }^{215}$ But the roots of the authoritarian state have remained firmly in place throughout the so-called transitional phase that ended when a former general, Abdel Fattah el- Sisi, became president in June 2014.

Despite such gloomy assessments, the question still remains whether authoritarian rule is sustainable in post-January $25 \mathrm{Egypt}$ where youth's access to social media and satellite television inform them about their government's failings and abuses. ${ }^{216}$ Moreover, the same factors that lead to the January 25 uprising still

212. See Heba Saleh, Human Rights Groups Fear Egypt Crackdown, FIN. TIMES (Nov. 9, 2014), http://www.ft.com/cms/s/0/c7978d80-65b0-1 le4-a454-00144feabdc0.html\#axzz3KQd66sXc.

213. See generally COOK, supra note 17.

214. Id. at 90-92.

215. Abigail Hauslohner \& Sharaf al-Hourani, Egyptian Court Orders Steel Tycoon Released, WASH. POST (Mar. 10, 2014), http://www.washingtonpost.com/world/egyptian-court-orders-steeltycoon-released/2014/03/10/a2408ade-a87b-11 e3-8a7b-clc684e2671f_story.html; Report: Former Egyptian President Hosni Mubarak to be Freed, Fox NEws (Aug. 19, 2013), http://www.foxnews.com/world/2013/08/19/mubarak-to-be-released-from-jail-this-week-report-says/.

216. See e.g., Clay Shirky, The Political Power of Social Media, 90 FOREIGN AFF. 28 (2011); Philip N. Howard, Aiden Duffy, Deen Freelon, Muzammil Hussain, Will Mari, Marwa Mazaid, Opening Closed Regimes: What was the Role of Social Media During the Arab Spring? (PITPI, Working Paper No. 1, 2011), available at http://pitpi.org/wp-content/uploads/2013/02/2011_Howard-Duffy-Freelon- 
exist. Overall unemployment rates stand at over $13 \%$ for the general public and $25 \%$ among youth, which are higher than 2010 rates. ${ }^{217}$ Current wages, especially for unskilled workers, are stuck at 1990 s wage levels. ${ }^{218}$ Annual inflation continues to hover near 10\%. Egypt's GDP has dropped to $2.3 \%$ in 2014 compared to $5.1 \%$ in 2010 just before the uprising. ${ }^{219}$ Electricity and fuel shortages are at unprecedented levels. ${ }^{220}$ Egypt's population of 90 million is growing at a rate of $1.7 \%$ while 5.6 million housing units are vacant despite an annual housing shortage of 3.5 million. ${ }^{221}$

Although the government claims, and some Egyptians believe, Egypt will regain stability under the firm hand of a military general, ${ }^{222}$ Egyptians have tasted the fruit of freedom even if for a brief moment. Egypt's youth, in particular, will not so easily accept another era of authoritarianism that suffocates their dreams and steals their future. They are wired to each other in a world wherein citizens now expect democratic political systems. Egyptians broke Mubarak's wall of fear, and they are likely to break the new walls currently being built under Egypt's new police state. Furthermore, the rapidly declining economic crisis coupled with pervasive corruption and a non-democratic political system is a recipe for instability. ${ }^{223}$

Although it postpones the inevitable, iron-fisted rule can prevent hungry, impoverished masses from revolting for only so long. At some point, President Sisi and his government will be held responsible for Egypt's myriad problems. Press censorship, military trials, anti-terrorism laws, and other anti-democratic practices cannot shield the government from a public that expects tangible improvements in their quality of life. Anything less is grounds for a real revolution.

Hussain-Mari-Mazaid_pITPI.pdf; Serajul I. Bhuiyan, Social Media and Its Effectiveness in the Political Reform Movement in Egypt,1 MIDDLE E. MEDIA EDUCATOR 14 (2011) available at http://ro.uow.edu.au/meme/voll/issl/3.

217. Sara Aggour, Unemployment Rates Reach 13.4\% in 3Q 2013, DAILY NEWS EGYPT (Nov. 17, 2013), http://www.dailynewsegypt.com/2013/11/17/unemployment-rates-reach-13-4-in-3q-2013; Egypt, Arab Rep., supra note 116 (reporting youth unemployment at $25 \%$ in 2010 ).

218. Akira Murata, Designing Youth Employment Policies in Egypt 15 (Global Econ. \& Dev. at Brookings, Working Paper No. 68, Jan. 2014), available at http://www.brookings.edu/ /media/research/files/papers/2014/01/31\%20youth\%20employment\%20egy pt $\% 20$ murata/arab\%20econpaper 3 murata $\% 20 v 5$.pdf.

219. Egypt, Real GDP Growth, GLOBAL FIN., https://www.gfmag.com/global-data/countrydata/egypt-gdp-country-report (last visited Jan. 6, 2015).

220. Rana Muhammad Taha, Misr Al-Qawia Criticises Lifting Natural Gas Prices, DaILy NEws EGYPT (Apr. 27, 2014), http://www.dailynewsegypt.com/2014/04/27/misr-al-qawia-criticises-liftingnatural-gas-prices; Albrecht, supra note 5, at 254 (discussing the unprecedented number of shortages for wheat, gas, and fuel).

221. Population Growth Chart, WORLD BANK, http://data.worldbank.org/indicator/SP.POP.GROW; Bel Trew, Multi-Billion Dollar Project Will Not Solve Egypt's Housing Crisis, AL-MONITOR (Mar. 2014), http://www.almonitor.com/pulse/originals/2014/03/egypt-housing-uae-arabtec-shortage.html; The World Factbook: Egypt, CENT. INTELLIGENCE AGENCY, https:/www.cia.gov/library/publications/the-worldfactbook/geos/eg.html (last visited Nov. 24, 2014) (noting the population and population growth rates).

222. See Hosni Mubarak Verdict Due, But Egyptians' Interest Wanes, WORLD Associated PRESS (Nov, 28, 2014), http://www.ndtv.com/article/world/hosni-mubarak-verdict-due-but-egyptians-interestwanes-626981

223. See, e.g., Ivekovic, supra note 15 , at 217. 


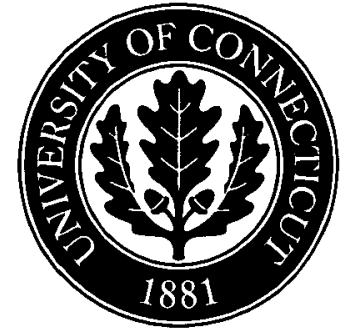

